\title{
Akıllı Telefon Kullanımının Karanlık Tarafı (Nomofobi): Endişelenmemize Gerek Var Mı?
}

\section{The Dark Side Of Smartphone Usage (Nomophobia): Do We Need To Worry About It?}

\author{
Dr. Baris Sezerl (ORCID: https://orcid.org/0000-0002-3436-1758) \\ Dr. Sevim Burge Ciftci Atilgan²(ORCID: https://orcid.org/0000-0002-2800-4957) \\ '(Assist.Prof., PhD) Faculty of Medicine, Department of Medical Education and Informatics, \\ Hacettepe University, Ankara, Turkey. E-mail: barissezer@hacettepe.edu.tr \\ ${ }^{2}$ (Res. Assistant, MD) Faculty of Medicine, Department of Medical Education and Informatics, \\ Hacettepe University, Ankara, Turkey. E-mail: atilganburge@gmail.com \\ Yazışma Adresi \\ Dr. Baris Sezer, +90 54251480 42, barissezer@hacettepe.edu.tr \\ Postal Address: Hacettepe University Faculty of Medicine Department of Medical Education and Informatics, \\ 06100 Sihhiye-Ankara, Turkey.
}

\section{Anahtar Sözcükler: \\ Nomofobi, Akıllı \\ telefonlar, Bağımlılık, \\ Sosyal izolasyon, \\ Akademik başarı.}

Keywords:

nomophobia,

smart phones, addiction, social isolation,

academic achievement.

Gönderilme Tarihi

Submitted:17.01.2019

Kabul Tarihi

Accepted: 28.02.2019

\section{ÖZET:}

Giriş ve Amaç: Nomofobinin sosyal ve psikolojik boyutları üzerine gerçekleştirilen çok sayıda araştırma mevcuttur. $\mathrm{Bu}$ araştırmada nomofobinin daha çok sosyodemografik boyutu üzerinde odaklanılmıştır. Tıp Fakültesi öğrencilerinin nomofobi düzeylerinin çeşitli değişkenlerle ilişkisinin ortaya koyulması amaçlanmıştır.

Gereç ve Yöntem: Araştırmanın katılımcılarını Hacettepe Üniversitesi Tip Fakültesinde öğrenimine devam eden 680 öğrenci oluşturmuştur. Veri toplama aracı olarak Nomofobi ve Yaşam Doyum Ölçeği kullanılmıştır.

Bulgular ve Sonuç: Çalışmada hekim adaylarının nomofobi düzeylerinin orta düzeyde olduğu saptanmış olup, nomofobinin akademik başarı ile ilgisi olduğu belirlenmiştir. Araştırmada cinsiyet, sınıf düzeyi ve birlikte yaşanılan kişi değişkenleri açısından öğrencilerin nomofobi düzeyleri açısından anlamlı farklılıklar bulunmazken, yaş, akademik başarı, yaşanılan yer ve yanında şarj aleti bulundurma değişkenleri açısından öğrencilerin nomofobi düzeyleri açısından anlamlı farklılıklar bulunmuştur.

Makale Künye Bilgisi: Sezer B, Atilgan SBC. The Dark Side Of Smartphone Usage (Nomophobia): Do We Need To Worry About It? Tip Eğitimi Dünyası. 2019;18(54): 30-43 
Araştırmanın bulguları üzerine uygulayıcılar ve gelecek araştırmalar için çeşitli öneriler getirilmiştir.

\section{ABSTRACT:}

Aim: There are so many studies about psychological and sociological aspects of nomophobia. We also investigated sociodemographic aspects of nomophobia. The present study aimed to examine nomophobia among the medical students, and its relationship with different variables.

Material and Method: Participants in the study were 680 medical students from the Faculty of Medicine of Hacettepe University. The Nomophobia Questionnaire and the Satisfaction with Life Scale were used as data collection instruments.

Results and Conclusion: It was found that students had moderate nomophobia and nomophobia was related to academic achievement. Our findings indicated that the prevalence of nomophobia does not vary by gender, class standing and living arrangements, whereas showed that students' nomophobia levels differed significantly with age, academic achievement, type of housing and carrying a phone charger. According to our findings, lots of suggestions were presented to practitioners and future studies.

\section{INTRODUCTION}

Fears of being deprived of one's smartphone/ device (nomophobia), of missing out on the latest developments (fear of missing out (FoMO)), and being unable to access the Internet (netlessphobia) are among the newly identified disorders brought about by the digital world(1). One such undesired phenomenon as a byproduct of the interaction between humans and new technologies, is nomophobia(2), which can be interpreted a phobia of the contemporary era (2-4). Nomophobia is a disorder of the modern, digital and virtual society, and refers to the discomfort, anxiety, irritability or pain associated with the inability to access one's mobile phone (5). These social and psychological conditions may be accompanied by physical symptoms such as spasms, excessive sweating, tachycardia, gastrointestinal problems and panic attacks $(2,6,7)$, which led (5) to propose that nomophobia be included in the Diagnostic and Statistical Manual of Mental Disorders-V (DSM-V), considering the extent of the associated stress, anxiety and tension and the speed at which it spreads. Symptoms of nomophobia include (5):

- Having one or more mobile devices and spending too much time on these devices,

- Being anxious about situations such as losing or being unable to access one's phone, not having it close by, not getting a signal or the battery running out,

- Purposefully avoiding places and situations in which the use of mobile devices is prohibited,

- Frequent checking of smartphones to see if there have been any new calls or messages,

- Keeping the smartphone open 24 hours a day, - Sleeping with a smartphone,

- Preferring virtual over face-to-face communication, and

- Excessive spending (borrowing) due to smartphone usage.

Nomophobic behaviors can alter our daily habits, and it has been proposed that they be treated as an addiction $(8,9)$. Spitzer reviewed the findings of 22 studies conducted in different countries on the risks, side effects and correlates of smartphone usage, and found an association 
with conditions such as sleep disorders, loneliness, addiction, depression, anxiety, increased alcohol and tobacco consumption, attention deficit and personality disorders, aggression and discontent (10). Rosen et al. found that students tended to keep their mobile devices on when they went to sleep, and many woke up at night to check notifications due to their addiction, which, in turn, affected their academic performance the next day, and similar observations were made among the faculty members $(10,11)$. Mendoza et al. found that the presence of mobile phones in the classroom had a negative effect on attention and learning in a study conducted with the participation of 554 dentistry students, and around 39.5 percent of the participants were found to receive lower grades in their exams when they spent too much time on their phones (12). In another study, the percentage of students who frequently checked their phones in the classroom or in clinical environments was found to be 24.7 percent (13). Moreover, 24.12 percent of the students were found to be nomophobic, and 40.97 percent more were found to be at risk of nomophobia. These findings show that many students are addicted to their cellphones, and that this has a negative impact on academic performance (13).

Similar studies conducted with medical students, who tend to have a very loaded curriculum, also called attention to the prevalence of nomophobia. Sharma et al. reported that 75 percent of medical students had nomophobia and 83 percent of participants had panic attacks when they were unable to access their cellphones (14). In a study conducted in India with the participation of 200 medical students aged 17-28, 18.5 percent of the students were found to be nomophobic, 73 percent of the students reported that they kept their phones close by when they went to sleep, and 20 percent reported that they lost concentration and felt stresses when they did not have their phones with them or if their phone batteries ran out (15). Pavithra et al. found that 23 percent of students experienced stress and concentration problems when their phone batteries/minutes were on the verge of running out, 39.5 percent were nomophobic and 27 percent were at risk of developing nomophobia (16). The anxiety and stress related to nomophobia in people's lives directly affects academic achievement (14). A study conducted in 2015 in Paraguay found that nomophobia was prevalent among medical students, concluding that academic performance had been negatively affected suggesting the preventative measures to be taken (17). Many students spend time on their mobile phones during class, mostly surfing the Internet and shopping $(12,18)$. According to a study, students who engage with their phones in an educational environment need 3.8 seconds to re-adapt to the course/class (19), while in another study, it was found that students who engaged with their phones in class received 30 percent lower marks in their exams when compared to students who did not engage with their phones (20). Many other studies have reported that the in-class use of these technologies can have a negative effect on attention, interest and motivation (21-24).In a conducted study, the self-esteem, extraversion, conscientiousness and emotional stability variables were found to be strong predictors of nomophobia (25). In another study, the use of social networking applications was found to be a significant predictor of mobile addiction (26). Literature recommends that more studies should be carried out into different aspects of nomophobia, being a relatively new area of study, and that the psychological and sociological aspects of nomophobia in particular 
should be examined further and in more detail (10,13,16,25,27-29). There have been numerous studies in literature examining the variables (age, gender, educational status, academic achievement, self-esteem, emotional stability etc.) associated with nomophobia $(17,27,28,30$ 33 ), but none about its effects on life satisfaction.

In this context, the present study aims to examine nomophobia among the students of the Faculty of Medicine at Hacettepe University, and its relationship with different variables. To this end, answers were sought to the following questions.

1. What are the levels of nomophobia among prospective physicians?

2. Do the levels of nomophobia among prospective physicians vary in accordance with the following variables?
a. Gender
b. Age
c. Class standing
d. Academic achievement
e. Type of housing
f. Living arrangements
g. Carrying a phone charger

3. Are the levels of nomophobia among prospective physicians related to their level of life satisfaction?

\section{Methods}

This study into the prevalence of nomophobia levels among prospective physicians (N: 680) uses a survey design to establish facts about the study topic (34). The ethical approval was obtained from Hacettepe University Ethics Committee (Date: 16 April 2018, Number: 35853172/431.10-1705).

\section{Participants}

The demographic characteristics of the students are reported in the Table 1.

\section{Data Collection Instrument}

The first data collection instrument used in the study was a questionnaire containing items on Age, Gender, Class standing, Grade point average (committee grade averages were used for students in their first year, and the grade point average was used for the other students), Type of housing, Living arrangements and Carrying a phone charger.

The second data collection instrument used in the study was the Nomophobia Questionnaire (NMP-Q) developed by Yildirim and Correia, 4 which was adapted to Turkish by Yildirim, Şumuer, Adnan and Yildirim (35). The questionnaire is answered on a seven-point Likert-type scale, with a total of 20 items. The original questionnaire had a Cronbach's alpha reliability coefficient of 0.95 , and the Turkish version had a reliability coefficient of 0.92 . The questionnaire has four sections: Inability to communicate (4 items), Losing connectedness (5 items), Inability to access information (6 items), and Giving up convenience (5 items).

The other data collection instrument used in the study was the Satisfaction with Life Scale (SWL) developed by Diener et al (36) and adapted to Turkish by Yetim (37), which measures the level of life satisfaction in individuals. The scale has a total of five items, all of them answered on a 7-point Likert-type scale.

\section{Data Collection and Analysis}

Analyses were carried out using the Statistical Package for the Social Sciences-SPSS 23.0 software package, and statistical techniques such as t-test, one-way analysis of variance (ANOVA) and Pearson's correlation coefficient 
Table 1. Demographic characteristics of the students

\begin{tabular}{lcc}
\hline Gender & $\mathbf{N}$ & $\%$ \\
\hline Female & 384 & 56.5 \\
Male & 296 & 43.5 \\
\hline
\end{tabular}

Age

21 and under

$\begin{array}{ll}180 & 27\end{array}$

21-23

$353 \quad 53$

24 and over

$133 \quad 20$

No response

14

\section{Class}

First year

$124 \quad 18.2$

Second year

$112 \quad 16.5$

Third year

$115 \quad 16.9$

Fourth year

$106 \quad 15.6$

Fifth year

$115 \quad 16.9$

Sixth year

$108 \quad 15.9$

\section{Grade point average}

$50-60$

$47 \quad 6.9$

61-70

$201 \quad 29.9$

$71-80$

$231 \quad 34.3$

$81-90$

$163 \quad 24.2$

$91-100$

$30 \quad 4.5$

No response 


\section{Type of housing}

Home

$420 \quad 62.8$

Dormitory

$253 \quad 37.2$

No response

7

\section{Living arrangements}

With family

$272 \quad 40.0$

With friend

$294 \quad 43.2$

\section{Alone}

$114 \quad 16.8$

\section{Carrying a phone charger}

Yes (always)

No

\section{Results}

Descriptive Statistics on Nomophobia and Life Satisfaction

Table 2 presents the descriptive data garnered from the nomophobia questionnaire used in the study. The mean total score on the Nomophobia Questionnaire ( $\bar{x}=75.58)$ indicates that prospective students have a moderate level of nomophobia. In terms of the individual dimensions of the questionnaire, the highest mean scores were received in the Not being able to communicate $(\overline{\mathrm{x}}=4.32)$, Not being able to access information $(\overline{\mathrm{x}}=4.25)$ and Losing connectedness $(\overline{\mathrm{x}}=3.95)$ variables, indicating moderate levels of nomophobia, followed by Giving up convenience $(\overline{\mathrm{x}}=2.56)$, indicating a mild level of nomophobia. The mean total score in the Satisfaction with Life Scale $(\bar{x}=22.23)$, on the other hand, indicates that prospective students are moderately satisfied with their lives (Table 3). 
Table 2. Nomophobia questionnaire factors and scores

\begin{tabular}{lllllll}
\hline Dimensions & N & Min & Max & Mean & SD & Mean/k* \\
& & & & & & \\
\hline $\begin{array}{l}\text { Not being able to access } \\
\text { information }\end{array}$ & 680 & 4 & 28 & 17.00 & 5.64 & 4.25 \\
& & & & & & \\
\hline
\end{tabular}

\begin{tabular}{lcccccc}
\hline Losing connectedness & 680 & 5 & 35 & 19.78 & 7.08 & 3.95 \\
& & & & & & \\
Not being able to communicate & 680 & 6 & 42 & 25.95 & 9.29 & 4.32 \\
& & & & & & \\
Giving up convenience & 680 & 5 & 35 & 12.83 & 7.47 & 2.56 \\
& & & & & & \\
\hline Total & & & & & & \\
\hline
\end{tabular}

Table 3. Scores on the satisfaction with life scale

\begin{tabular}{lllllll}
\hline & N & Min & Max & Mean & SD & Mean/k \\
& & & & & & \\
\hline SWL Scale & 680 & 5 & 33 & 22.24 & 6.22 & 4.44 \\
\hline
\end{tabular}

\footnotetext{
${ }^{*} \mathrm{k}=$ Item number
} 


\section{Variation in Nomophobia and Life}

Satisfaction levels by different variables

\section{Gender-Related Findings}

An independent samples t-test was conducted to identify whether the prospective physicians' nomophobia levels varied by gender. The results of the independent samples t-test revealed no statistically significant differences between the male $(\bar{x}=72.51)$ and female $(\bar{x}=77.95)$ students in terms of their nomophobia levels $[\mathrm{t}(678)=2.98$, $\mathrm{p}>.05]$. This finding indicates that the prevalence of nomophobia does not vary by gender, female students were found to have higher levels of life satisfaction than male students.

\section{Age-Related Findings}

A one-way analysis of variance (ANOVA) was conducted to identify whether the nomophobia levels of prospective physicians varied with age. The results of the analysis showed that students' nomophobia levels differed significantly with age $F(2,661)=5.274, p=.000]$. A Tukey test was conducted to find out which groups differed from one another, and the results identified a difference between students aged 20 and under $(\overline{\mathrm{x}}=79.23)$ and those aged $21-23(\overline{\mathrm{x}}=72.86)$.

\section{Findings on Class Standing}

A one-way analysis of variance was conducted to identify whether the prospective physicians' nomophobia levels varied with class standing. The results of the analysis showed that students' nomophobia levels did not differ significantly with class standing $[\mathrm{F}(5,674)=2.227, \mathrm{p}=.050]$.

\section{Findings on Academic Achievement}

A one-way analysis of variance was conducted to identify whether prospective physicians' levels varied with academic achievement. The results of the analysis showed that students' nomophobia levels differed significantly by academic achievement $[\mathrm{F}(4,667)=4.264$, $\mathrm{p}=.002]$. A Tukey test was conducted to find out which groups differed from one another, and the results showed that students with grades 50 to 60 differed from students with grades 81 to 90 and 91 to 100 . In other words, students with lower and higher levels of academic achievement differed from one another.

\section{Findings on Type of Housing}

An independent samples t-test was conducted to identify whether nomophobia levels among prospective physicians varied by type of housing, and the results of the independent samples t-test showed that there was a statistically significant difference between students staying in dorms $(\overline{\mathrm{x}}=77.54)$ and those staying in apartments $(\bar{x}=74.29)$ in terms of their nomophobia levels $[\mathrm{t}(671)=1.723, \mathrm{p}<.05]$. This finding indicates that the prevalence of nomophobia varies by type of housing.

\section{Findings on Living Arrangements}

A one-way analysis of variance was conducted to identify whether nomophobia levels among prospective physicians varied by living arrangements, and the results of the analysis showed that students' nomophobia levels did not differ significantly by living arrangements $[\mathrm{F}(2,667)=1.892, \mathrm{p}=.152]$.

\section{Findings on Carrying a Phone Charger}

A one-way analysis of variance was conducted to identify whether prospective physicians' nomophobia levels varied based on whether or not the respondent carries a phone charger, and the results of the analysis showed that students' nomophobia levels differed significantly in relation to whether or not they carried a phone charger $\left[\mathrm{F}(2,677)=25.118, \mathrm{p}=.000^{*}\right]$. A Tukey 
test was conducted to find out which groups differed from one another, and the results showed that there were significant differences between all three groups. (Always carry, $\overline{\mathrm{x}}=86.62$; Sometimes carry, $\overline{\mathrm{x}}=77.03$; Never carry, $\overline{\mathrm{x}}=67.76$ )

\section{Relationship between Nomophobia and Life Satisfaction}

In order to answer the third research question, a Pearson correlation test was conducted to examine the relationship between nomophobia and life satisfaction levels, and the two were found to be unrelated $(\mathrm{r} 680=.040, \mathrm{p}>.05)$.

\section{Discussion}

The present study has examined the prevalence of nomophobia levels among prospective physicians, and found that students who participated in the study had moderate nomophobia, that is to say, they displayed nomophobic behaviors, concurring with many studies in literature that have also reported the prevalence of nomophobia among college students $(14,30,35,38,39)$. The study found that the dimensions of "Not being able to communicate" and "Not being able to access information" were particularly important for the participants, and similar findings were also reported by Adnan and Gezgin (30).

The present study found that both nomophobia was related to academic achievement. There is no doubt that mobile technologies are a part of our lives, and to turn this fact into an educational opportunity, attention must be paid to integrating mobile phones into education. E-learning has been gaining widespread popularity in higher education institutions (40-43), particularly with the spread of Internet technologies, and this rise in popularity has played a facilitating role in lowering costs, improving student attention and meeting educational needs (44). In a study conducted by Allen and Seaman (45), it was found that 69 percent of higher education institutions used e-learning systems, believing this system to be the most important building block in achieving long-term educational success. Many colleges use educational systems (electronic problem-based learning, taskbased learning, flipped classroom, anchored learning etc.) that are integrated with different technologies, and an institutional effort to integrate these methods into education may help overcome the limitations of traditional education and motivate the technologically savvy Y generation $(46,47)$. There are many educational applications that are offered free of charge to support these goals. Free educational software/systems/programs including learning management systems (Moodle), educational instant quizzes (Kahoot), interactive videos (edpuzzle) and educational social media tools (edmodo) have been used in different classes in our university, and have been found to be useful in motivating students (48). Literature suggests that the number one reason for the use of mobile phones in school among students is to access social networks $(49,50)$, and so social networks may be blocked through Wi-Fi connections on campus to prevent access.

The study identified no significant differences in the nomophobia levels of students on the basis of gender, class standing or living arrangements, although there have been different findings in literature in this regard, particularly concerning the Gender variable. There have been studies reporting that women are more nomophobic $(35,39,51)$, while others have failed to identify any gender-related differences, as is the case in the present study $(15,30)$. This issue seems to be 
in need of further research, and may benefit by being supported by qualitative data.

The study found significant differences in the students' nomophobia levels by age, academic achievement, type of housing and carrying a phone charger. The findings concerning the variables of academic achievement and type of housing, in particular, need to be paid close attention. A significant relationship was found between nomophobia levels and academic achievement, with nomophobic students found to have lower levels of academic success. This finding should be examined in detail in future studies, and factors such as lack of sleep, failure to attend classes or spending time on mobile devices in class should be studied to see which are responsible for lower grades. Another finding was that students who lived in dorms were more nomophobic than those who lived in apartments, which can probably be attributed to such factors as lack of social activities in dorms, social isolation or missing family members, although this issue should be examined in detail in future studies.

\section{Recommendations for Practitioners}

- The orientation events that are organized in many universities for students who are starting out in college should provide information about nomophobia, and awareness should be raised in the very beginning of the students' college lives.

- Psychological counselling offices should track the social environments and academic achievement levels of students, examine their nomophobia and life satisfaction levels, and take remedial measures.

- Free applications that integrate smartphones into education should be introduced to instructors and students, especially for classes conducted in large lecture halls, with a budget sourced for paid, and the educational use of mobile technologies both in class and outside class should be supported.

- Mentoring services should be offered to students with low levels of academic achievement, and remedial measures should be taken by ensuring one-on-one student-faculty interaction.

- Social activities should be held for students staying in dorms. Students suffering from social isolation should be identified and preventive measures should be taken.

\section{Recommendations for Future Studies}

- Qualitative studies should be conducted to examine the problems experience by students displaying nomophobic behaviors in more detail. In addition, reasons for the decline in life satisfaction as students advance through their studies should be examined.

- Further research should be conducted on other variables considered to be related to nomophobia in academic environments where mobile learning is actively used.

- Training programs on nomophobia should be offered, and the long-term effects, if any, of these programs should be examined.

\section{References}

1. Yıldırım S, Kişioğlu AN. New diseases due to technology: nomophobia, netlessphobia, FoMO. Medical Journal of SDU 2018; 1: 1-13. doi: $10.17343 /$ sdutfd. 380640

2. King ALS, Valença AM, Nardi AE. Nomophobia: the mobile phone in panic disorder with agoraphobia: reducing phobias or worsening of dependence? Cognitive, Behavioral Neurology 2010; 23(1): 52-54. 
3. King ALS, Valença, AM, Silva ACO, Baczynski T, Carvalho MR, Nardi AE. Nomophobia: Dependency on virtual environments or social phobia?. Computers in Human Behavior 2013; 29(1): 140-144.

4. Yildirim C, Correia AP. Exploring the dimensions of nomophobia: Development, validation of a self-reported questionnaire. Computers in Human Behavior 2015; 49: 130137.

5. Bragazzi NL, Puente GD. A proposal for including nomophobia in the new DSM-V. Psychological Research Behavior Management 2014; 7: 155-160.

6. Riedl R, Mohr PN, Kenning PH, Davis FD, Heekeren HR. Trusting humans, avatars: A brain imaging study based on evolution theory. Journal of Management Information Systems 2014; 30(4): 83-114.

\section{Tams S, Legoux R, Léger PM. Smartphone} withdrawal creates stress: A moderated mediation model of nomophobia, social threat, phone withdrawal context. Computers in Human Behavior 2018; 81: 1-9.

8. Emanuel $\mathrm{R}$ et al. The truth about smartphone addiction. College Student Journal, 2015; 49, 291-299.

9. Lukacs A, Tavolacci MP, Kiss-Toth E, Sasvar P, Ladner J (2016, July) Internet addiction in university students: Cross-border study in Algeria, France, Hungary. Paper presented at 5th European Symposium on Substance Use, other Health Behaviours in Students Conference 30th June, 1st July 2016, Rouen, France.
10. Spitzer M. M-Learning? When it comes to learning, smartphones are a liability, not an asset. Trends in Neuroscience, Education 2015; 4(4): 87-91.

11. Rosen L, Carrier LM, Miller A, Rokkum J, Ruiz A. Sleeping with technology: cognitive, affective, technology usage predictors of sleep problems among college students. Sleep Health 2016; 2(1): 49-56.

12. Mendoza JS, Pody BC, Lee S, Kim M, McDonough IM. The effect of cellphones on attention, learning: The influences of time, distraction, nomophobia. Computers in Human Behavior 2018; 86: 52-60.

13. Prasad M, Patthi B, Singla A, Gupta R, Saha S, Kumar JK, ..., Pandita V. Nomophobia: a cross-sectional study to assess mobile phone usage among dental students. Journal of clinical, diagnostic research: JCDR 2017; 11(2): ZC34.

14. Sharma N, Sharma P, Sharma N, Wavare RR. Rising concern of nomophobia amongst Indian medical students. International Journal of Research in Medical Sciences 2017; 3(3): 705-707.

15. Dixit S, Shukla H, Bhagwat AK, Bindal A, Goyal A, Zaidi AK, Shrivastava A. A study to evaluate mobile phone dependence among students of a medical college, associated hospital of central India. Indian journal of community medicine: official publication of Indian Association of Preventive, Social Medicine 2010; 35(2): 339-351.

16. Pavithra MB, Madhukumar S, Mahadeva M. A study on nomophobia-mobile phone dependence, among students of a medical 
college in Bangalore. National Journal of community medicine 2015; 6(3): 340-344.

17. Tams S, Hill K, de Guinea AO, Thatcher J, Grover V. Neuro-ISdalternative or complement to existing Methods? Illustrating the holistic effects of neuroscience, selfreported data in the context of technostress research. Journal of the Association for Information Systems 2014; 15(10): 723-752.

18. Carrier L. M, Cheever NA, Rosen LD, Benitez S, Chang J. Multitasking across generations: Multitasking choices, difficulty ratings in three generations of Americans. Computers in Human Behavior 2009; 25: 483489. https://doi.org/10.1016/j.chb.2008.10.012

19. Thapa R, Codjoe J, Ishak S, McCarter KS. Post, during event effect of cellphone talking, texting on driving performanceda driving simulator study. Traffic Injury Prevention 2015; 16: 461-467. https://doi.org/10.1080/15389588. 2014.969803.

20. Froese $\mathrm{AD}$, Carpenter $\mathrm{CN}$, Inman DA, Schooley JR, Barnes RB, Brecht PW et al. Effects of classroom cellphone use on expected, actual learning. College Student Journal 2012; 46: 323-333.

21. Dietz S, Henrich C. Texting as a distraction to learning in college students. Computers in Human Behavior 2014; 36: 163-167. https://doi. org/10.1016/j.chb.2014.03.045.

22. Lee YK, Chang CT, Lin Y, Cheng ZH. The dark side of smartphone usage: Psychological traits, compulsive behavior, technostress. Computers in Human Behavior 2014; 31: 373383. https://doi.org/10.1016/j.chb.2013.10.047.
23. Thornton B, Faires A, Robbins M, Rollins E. The mere presence of a cellphone may be distracting. Social Psychology 2014; 45: 479-488. https://doi.org/10.1027/1864- 9335/ a000216.

24. Ward AF, Duke K, Gneezy A, Bos MW. Brain Drain: The mere presence of One's own smartphone reduces available cognitive capacity. Journal of the Association for Consumer Research 2017; 2: 140-154. https:// doi.org/10.1086/691462.

25. Argumosa, L, Boada J, Vigil-Colet R. Exploratory investigation of theoretical predictors of nomophobia using the Mobile Phone Involvement Questionnaire (MPIQ). Journal of adolescence, 2017; 56: 127-135.

26. Salehan M, Negahban A. Social networking on smartphones: When mobile phones become addictive. Computers in Human Behavior 2013; 29(6): 2632-2639.

27. Lepp A, Barkley JE, Karpinski, AC. The relationship between cell phone use, academic performance in a sample of US college students. Sage Open 2015; 5(1): 1-14.

28. Samaha M, Hawi NS. Relationships among smartphone addiction, stress, academic performance, satisfaction with life. Computers in Human Behavior 2016; 57: 321-325.

29. Sirakaya M. Examination of Associate Students' Nomophobia Levels According to Smart Phone Use. Mersin University Journal of the Faculty of Education 2018; 14(2): 714-727.

30. Adnan M, Gezgin DM. A modern phobia: Prevalence of nomophobia among college 
students. Egitim Bilimleri Fakultesi Dergisi 2016; 49(1): 141-152.

31. Bianchi, A, Phillips JG. Psychological predictors of problem mobile phone use. CyberPsychology \& Behavior, 2005, 8.1: 39-51.

32. JB B, et al. Nomophobia-Do We Really Need to Worry About?. Reviews of Progress, 2013; 1: 27-32.

33. Jacobsen WC, Forste R. The wired generation: Academic, social outcomes of electronic media use among university students. Cyberpsychology, Behavior,, Social Networking 2011; 14(5): 275-280.

34. Büyüköztürk Ş, Çakmak EK, Akgün ÖE, Karadeniz Ş, Demirel F (2015) Bilimsel Araştırma Yöntemleri (Scientific Research Methods), Ankara: Pegem.

35. Yıldırım C, Şumuer E, Adnan M, Yıldırım S. A growing fear Prevalence of nomophobia among Turkish college students. Information Development 2016; 32(5): 1322-1331.

36. Diener, E. Subjective Well-Being The Science of Happiness and a Proposal for a National

Index. American Psychologist, psycnet.apa.org, (2000)

37. Yetim U. Life satisfaction: A study based on the organization of personal projects. Social Indicators Research 1993; 29: 277-289.

38. Farooqui IA, Pore P, Gothankar J. Nomophobia: an emerging issue in medical institutions?. Journal of Mental Health 2017; 12: 1-4.
39. Tavolacci MP, Meyrignac G, Richard L, Dechelotte P, Ladner J. Problematic use of mobile phone, nomophobia among French college studentsMarie-Pierre Tavolacci. European Journal of Public Health 2015; 25(3): 12-21.

40. Al-Samarraie H, Eldenfria A, Dawoud H. The impact of personality traits on users' information-seeking behavior. Information Processing, Management 2017; 53(1): 237- 247.

41. Ansong E, Lovia-Boateng S, Boateng R. Determinants of E-Learning Adoption in Universities: Evidence From a Developing Country. Journal of Educational Technology Systems 2017; 46(1): 30-60.

42. Goh PS. eLearning or technology enhanced learning in medical education-Hope, not hype. Medical teacher 2016; 38(9), 957-958.

43. McConnell. E-learning in Chinese higher education: the view from inside. Higher Education 2018; 75(6): 1031-1045.

44. Arpaci, I. A comparative study of the effects of cultural differences on the adoption of mobile learning. British Journal of Educational Technology, 2015; 46.4: 699-712.

45. Allen II, Seaman, J. (2013) Changing course: Ten years of tracking online education in the United States. Sloan Consortium. PO Box 1238, Newburyport, MA 01950, 2013.

46. Moreno-Walton L, et al. Teaching across the generation gap: a consensus from the Council of Emergency Medicine Residency Directors 2009 academic assembly. Academic emergency medicine, 2009; 16: S19-S24. 
47. Sezer B, Yilmaz R. Learning management system acceptance scale (LMSAS): A validity, reliability study. Australasian Journal of Educational Technology, 2019; 35: 3-17.

48. Sezer B. Faculty of medicine students' attitudes towards electronic learning, their opinion for an example of distance learning application. Computers in Human Behavior, 2016; 55: 932-939.

49. Sezer B, Simsek N. The circumstances of using technological applications inside, outside of the faculty by physician, nurse candidates. Journal of Clinical and Analytical Medicine 2016; 7:13-19.

50. Sethia S, Melwani V, Melwani S, Priya A, Gupta M, Khan A. A study to assess the degree of nomophobia among the undergraduate students of a medical college in Bhopal.International Journal of Community Medicine, Public Health 2018; 5(6): 2442-2445.

51. SecurEnvoy. $66 \%$ of the population suffer from nomophobia the fear of being without their phone (2012). 